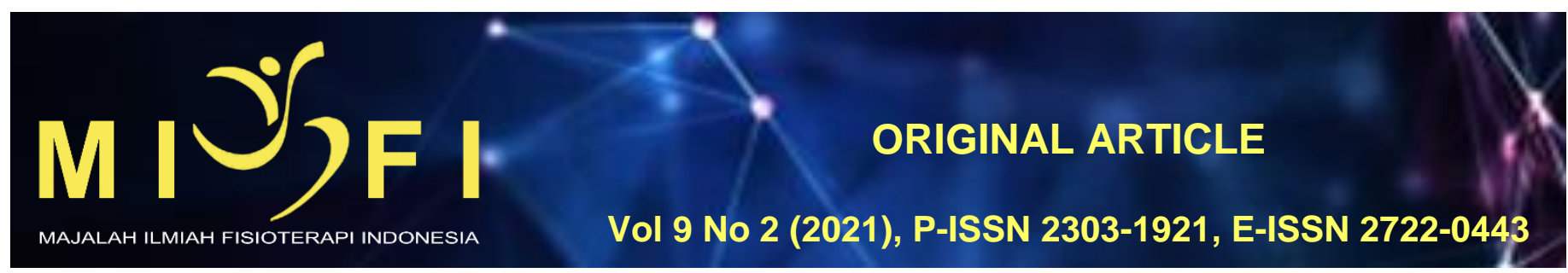

\title{
PERBEDAAN EFEKTIFITAS LATIHAN KEKUATAN OTOT GENGGAM HAND GRIPPER EXERCISE DENGAN ISOMETRIC STRENGTHENING WRIST DALAM MENINGKATKAN KEMAMPUAN AKTIVITAS FUNGSIONAL PADA LANSIA DI BANJAR SANGLAH UTARA DENPASAR
}

\author{
Anjani Septania Soegiharto ${ }^{1}$, Ni Luh Nopi Andayani ${ }^{2}$, Ni Komang Ayu Juni Antari ${ }^{3}$, I Made Winarsa Ruma \\ ${ }_{1}^{1}$ Program Studi Sarjana Fisioterapi dan Profesi Fisioterapi Fakultas Kedokteran Universitas Udayana,Denpasar, Bali \\ 2,3Departemen Fisioterapi, Fakultas Kedokteran Universitas Udayana, Denpasar, Bali \\ ${ }^{4}$ Departemen Biokimia, Fakultas Kedokteran Universitas Udayana, Denpasar, Bali \\ anjani.septania@gmail.com
}

\begin{abstract}
ABSTRAK
Kekuatan Genggam Tangan adalah ukuran yang digunakan untuk mengukur seberapa kuat ekstremitas atas dengan memperhatikan posisi saat latihan. Pada lansia kekuatan otot akan berkurang 10-25\% pada saat usia kurang lebih 60 tahun keatas. Penelitian ini bertujuan untuk mengetahui perbedaan efektifitas latihan kekuatan otot genggam Hand Gripper Exercise dan Isometric Strengthening Wrist dalam meningkatkan kemampuan aktivitas fungsional pada lansia di Banjar Sanglah Utara Denpasar. Penelitian ini merupakan penelitian eksperimental dengan metode pre test dan post test design dengan teknik pengambilan sampel yaitu purposive sampling dengan jumlah sampel 20 orang. Sampel dibagi menjadi 2 kelompok perlakuan yaitu Kelompok Hand Gripper Exercise dan Isometric Strengthening Wrist. Pada penelitian ini terdapat statistik deskriptif berupa usia, IADL, IMT dan kekuatan otot genggam.

Kata kunci : latihan kekuatan otot genggam, aktivitas fungsional lansia
\end{abstract}

\section{DIFFERENCES IN THE EFFECTIVENESS OF HANDLED MUSCLE STRENGTH OF HAND GRIPPER STRENGTH AND ISOMETRIC STRENGTHENING WRIST IN IMPROVING FUNCTIONAL ACTIVITY SKILLS IN ELDERLY IN BANJAR SANGLAH UTARA DENPASAR}

\section{ABSTRACT}

The hand gripper strength is measurement used to measure how strong upper extremity by observing position when exercise. For the elder hand gripper would be decrease 10-25\% when about above 60 years. This research aimed at discover the differences between effectiveness of handled muscle strength of hand gripper exercise and isometric strengthening wrist in increasing functional activity ability of the elderly at Banjar Sanglah Utara Denpasar. This study was experimental research design by using pre-test and post-test with purposive sampling with 20 people. It was divided into two groups; they were hand gripper exercise group and isometric strengthening wrist group. There was descriptive statistics in a form of age, IADL, IMT, and handled muscle strength.

Keywords: handheld muscle strength exercise, functional activity of the elderly

\section{PENDAHULUAN}

Kualitas hidup setiap individu dapat dilihat dari kemampuannya dalam melakukan kegiatan sehari-hari. Mulai dari hal yang berhubungan dengan diri sendiri hingga orang lain. Hal ini juga dapat dipengaruhi oleh beberapa faktor yaitu usia, sosial, dan lingkungan. Usia merupakan faktor utama dalam pengukuran kemampuan aktivitas seseorang. Individu tidak dapat lepas dari proses penuaan yang harus dialami oleh setiap manusia.

Penuaan adalah proses alamiah yang merupakan sebuah fase akhir dari perkembangan manusia. Penuaan ditandai dengan berbagai perubahan dalam fisik, mental, maupun sosial. ${ }^{1}$ Proses penuaan dalam segi fisik ditandai dengan adanya penurunan kemampuan jaringan dalam mempertahankan fungsi normalnya sehingga tidak lagi mampu memperbaiki kerusakan yang ada. ${ }^{2}$ Menurut World Health Organization lanjut usia (lansia) adalah kelompok penduduk dengan usia 60 tahun atau lebih. ${ }^{3}$ Data WHO menunjukkan pada tahun 2009 lansia berjumlah 7,49\% dari total populasi,

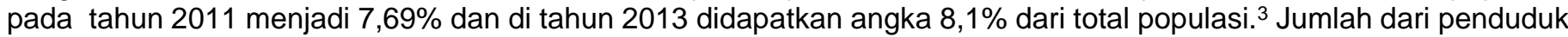
lansia di Indonesia adalah 9,1 juta jiwa dan jumlah dari penduduk non lansia 254,9 juta jiwa. ${ }^{4}$ Menurut Badan Pusat Statistik Penduduk Kota Denpasar, jumlah penduduk Kecamatan Denpasar Barat kurang lebih pada tahun 2016 sebanyak 10.379 jiwa / km². Kecamatan Denpasar Barat terdiri dari 8 desa dan 3 kelurahan, salah satunya adalah Banjar Sanglah Utara. ${ }^{5}$ Banjar Sanglah Utara memiliki perkumpulan senam lansia yang cukup terkenal di Denpasar. Pekumpulan senam sehat lansia ini mengembangkan program pemeliharaan kesehatan lansia untuk mengurangi angka morbiditas.

Lansia sering mengalami satu atau lebih keterbatasan dalam melakukan aktivitas fungsionalnya. Aktivitas fungsional merupakan kemampuan seseorang dalam menggunakan kapasitas fisik yang memiliki kegunaan untuk menjalankan aktivitas sehari-hari dengan baik. Hal tersebut adalah salah satu pemicu angka morbiditas dan mortalitas lansia menjadi tinggi. ${ }^{5}$ Menurut Badan Pusat Statistik Penduduk, lansia tahun 2014 memiliki angka morbiditas sebesar $25,05 \%$ yang berarti bahwa sekitar satu per empat dari jumlah lansia mengalami sakit dalam satu bulan terakhir. ${ }^{5}$ Rentannya lansia dalam mengalami kondisi sakit salah satunya disebabkan oleh adanya perubahan fisik seperti 
menurunnya kekuatan otot dan kekakuan pada sendi. ${ }^{6}$ Menurut American Medical Association memperkirakan bahwa $10-25 \%$ orang di atas 60 tahun memiliki kekuatan otot yang lemah dan prevalensi ini meningkat secara proposional dengan bertambahnya usia. ${ }^{6}$

Kekuatan otot merupakan salah satu aspek penting yang dapat menyebabkan menurunnya kemandirian lansia atau menjadi tergantung pada orang lain. Lansia memiliki nilai rasio ketergantungan sebesar $12,71 \%$ yang berarti bahwa 100 orang penduduk usia produktif harus mampu menanggung sekitar 13 orang lansia. ${ }^{5}$ Kekuatan otot yang akan mengalami penurunan salah satunya adalah kekuatan otot gengam. ${ }^{7}$ Kekuatan otot genggam (Hand Grip Strength) adalah ukuran yang dapat digunakan untuk intregitas ekstrimitas atas, dengan berbagai macam posisi yaitu terlentang, duduk, dan berdiri, yang dilakukan tanpa penekanan. ${ }^{7}$

Setiap individu khususnya lansia menghadapi kesulitan dalam melakukan aktivitas hidup sehari-hari seperti mengikat tali sepatu, menulis, dan menekan tombol pada alat komunikasi. ${ }^{7}$ Dikatakan bahwa lansia mengalami penurunan sensasi pada tangan dan penurunan jari manipulatif seperti mengontrol kekuatan jari-jari tangan akibat dari degeneratif sistem sensorimotor penuaan. ${ }^{8}$ Penurunan sistem sensorimotor ini perlu dilakukan latihan untuk meningkatkan kekuatan otot genggam. ${ }^{8}$

Kekuatan otot genggam ini dapat ditingkatkan dengan latihan menggunakan hand gripper yang berukuran 5 $\mathrm{kg} .{ }^{9}$ Menurut penelitian menyatakan bahwa latihan menggunakan hand gripper dapat meningkatkan kekuatan otot genggam dengan cara meletakkan tangan di lengan kursi, siku flexi $90^{\circ}$,dan lengan bawah serta pergelangan tangan tetap dalam posisi netral. ${ }^{10}$ Kekuatan otot genggam juga dapat ditingkatkan dengan latihan isometric strengthening wrist. Latihan isometric strengthening wrist bertujuan untuk mengaktifkan otot ekstensor dan pinch grip lateral. ${ }^{9}$

Meningkatkan kekuatan otot genggam adalah salah satu program pemeliharan kesehatan, maka dari itu perlu dilakukan untuk membantu meningkatkan aktivitas fungsional pada lansia. Berdasarkan latar belakang di atas, perlu dilakukan penelitian tentang perbedaan efektifitas latihan kekuatan otot genggam hand gripper exercise dengan isometric strengthening wrist dalam meningkatkan kemampuan aktivitas fungsional pada lansia di Banjar Sanglah Utara Denpasar.

\section{METODE}

Penelitian ini menggunakan desain penelitian eksperimental dengan menggunakan metode pendekatan pre test dan post test group design yang telah dilakukan pada bulan Mei-Juni 2019, nomor: 370/UN 14.2.2VII.14/LP/2019 di Banjar Sanglah Utara Denpasar. Penelitian ini telah disetujui oleh Komite Etik Penelitian Fakultas Kedokteran Udayana tertanggal 22 Februari 2019. Teknik yang digunakan untuk penentuan sampel adalah purposive sampling. Total sampel penelitian ini adalah 20 orang. Sampel didapat melalui kriteria inklusi yaitu lansia berumur $60-80$ tahun, lansia harus memiliki vital sign yang normal, mampu mengaplikasikan telepon genggam, dan mampu berkomunikasi secara verbal serta kriteria eksklusi yaitu responden tidak pernah mengalami cidera pada bagian wrist and hand, tidak terdapat gangguan neurologis, dan respoden tidak sedang mengonsumsi obat-obatan yang mempengaruhi kekuatan otot.

Variabel indenpenden dalam penelitian ini adalah latihan kekuatan otot genggam hand gripper exercise dan isometric strengthening wrist serta kemampuan aktivitas fungsional lansia sebagai variabel dependen, sedangkan variabel kontrol dalam penelitian ini yaitu vital sign dan usia. Pertama, responden akan diminta persetujuan mengkuti penelitian ini dengan mengisi inform concent, kedua responden akan di anamnesis, dan ketiga responden akan mengikuti rangkaian latihan selama 5 minggu. Aplikasi statistika berupa SPSS versi 16.0 digunakan untuk analisis dan olah data. Hasil data yang diperoleh akan diuji analasis menggunakan uji statistik deskriptif, uji normalitas, uji homogenitas data dengan Saphiro-Wilk test, dan uji hipotesis.

\section{HASIL}

Sampel dalam penelitian ini merupakan lansia di Banjar Sanglah Utara Denpasar. Pada rentang usia 60-78 tahun, pengambilan sampel dengan menggunakan metode purposive sampling yang sudah memenuhi kriteria inklusi dan eksklusi. Sesuai dengan rumus yang digunakan maka jumlah sampel dalam penelitian ini adalah 20 orang yang terdiri dari dua kelompok yaitu kelompok dengan pemberian Hand Gripper Exercise dan kelompok pemberian Isometric Strengthening Wrist masing-masing sebanyak 10 orang. Berikut adalah tabel analisis data penelitian.

Tabel 1. Karakteristik Responden Berdasarkan Usia

\begin{tabular}{cccc}
\hline Kelompok & Mean \pm SD & $\mathrm{P}$ value & Keterangan \\
\hline Hand gripper exercise & $69,1 \pm 6,31$ & \multirow{2}{*}{0,762} & Tidak \\
Isometric strengthening wrist & $69,9 \pm 5,25$ & & Berbeda \\
\hline
\end{tabular}

Tabel 1. menunjukkan bahwa dari 20 sampel yang diamati, dapat di informasikan bahwa rerata usia sampel pada kelompok Hand Gripper Exercise 69,1 yang menurut WHO pada tahun 2013 termasuk dalam katergori usia lanjut (60-74 tahun), sedangkan pada kelompok Isometric Strengthening Wrist rerata sampel didapatkan nilai 69,9 yang menurut WHO tahun 2013 termasuk dalam kategori usia lanjut (60-74 tahun). Setelah dilakukan pengujian pada usia kedua kelompok diketahui nilai p sebesar 0,762 yang dapat diartikan bahwa tidak ada perbedaan usia yang signifikan pada kedua kelompok tersebut. ${ }^{3}$

Tabel 2. Karakteristik Responden berdasarkan Kekuatan Otot Genggam Sebelum Melakukan Latihan

\begin{tabular}{cccc}
\hline Kelompok & Mean \pm SD & $\mathrm{P}$ value & Keterangan \\
\hline Hand gripper exercise & $16,75 \pm 7,34$ & 0,171 & Tidak Berbeda \\
Isometric strengthening wrist & $12,54 \pm 5,80$ & 0,11 & \\
\hline
\end{tabular}


Tabel 2. menunjukkan bahwa dari 20 sampel yang diamati, dapat di informasikan bahwa rerata kekuatan otot genggam sebelum diberikannya latihan, pada kelompok Hand Gripper Exercise 16,75 menurut Ryoto tahun 2012 termasuk dalam klasifikasi kekuatan otot genggam yang kurang, sedangkan pada kelompok Isometric Strengthening Wrist rerata sampel didapatkan nilai 12,54 yang menurut Ryoto tahun 2012 termasuk dalam klasifikasi kekuatan otot genggam kurang. Setelah dilakukan pengujian pada kekuatan otot genggam sebelum melakukan latihan, kedua kelompok menghasilkan nilai p sebesar 0,171 yang dapat diartikan bahwa tidak ada perbedaan kekuatan otot genggam sebelum melakukan latihan yang signifikan pada kedua kelompok tersebut. ${ }^{18}$

Tabel 3. Karakteristik Responden berdasarkan berdasarkan Intermediate Activity Daily Living Sebelum Melakukan Latihan

\begin{tabular}{cccc}
\hline Kelompok & Mean \pm SD & P value & Keterangan \\
\hline Hand gripper exercise & $13,30 \pm 1,33$ & \multirow{2}{*}{0,245} & \multirow{2}{*}{ Tidak Berbeda } \\
Isometric strengthening wrist & $12,60 \pm 1,26$ & & \\
\hline
\end{tabular}

Tabel 3. menunjukkan bahwa dari 20 sampel yang diamati, dapat di informasikan bahwa rerata Intermediate Activity Daily Living sebelum diberikannya latihan, pada kelompok Hand Gripper Exercise sebesar 13,30 menurut Kemenkes RI tahun 2016 termasuk dalam kategori ketegantungan ringan sedangkan pada kelompok Isometric Strengthening Wrist sebesar 12,60 nilai tersebut memiliki definisi ketergantungan ringan. Setelah dilakukan pengujian pada Intermediate Activity Daily Living kedua kelompok diketahui nilai p sebesar 0,245 yang dapat diartikan bahwa tidak ada perbedaan Intermediate Activity Daily Living yang signifikan pada kedua kelompok tersebut. ${ }^{19}$

Tabel 4. Karakteristik Responden berdasarkan berdasarkan Indeks Massa Tubuh

\begin{tabular}{cccc}
\hline Kelompok & Mean \pm SD & $\mathrm{P}$ value & Keterangan \\
\hline Hand gripper exercise & $23,35 \pm 2,80$ & \multirow{2}{*}{0,861} & \multirow{2}{*}{ Tidak Berbeda } \\
Isometric strengthening wrist & $23,56 \pm 2,13$ & & \\
\hline
\end{tabular}

Tabel 4. menunjukkan bahwa dari 20 sampel yang diamati, dapat di informasikan bahwa rerata Indeks Massa Tubuh, pada kelompok Hand Gripper Exercise 23,35 menurut Kemenkes RI tahun 2016 termasuk dalam kategori IMT normal sedangkan pada kelompok Isometric Strengthening Wrist sebesar 23,56 skor tersebut memiliki definisi IMT yang normal. Setelah dilakukan pengujian pada Indeks Massa Tubuh kedua kelompok diketahui nilai p sebesar 0,861 yang dapat diartikan bahwa tidak ada perbedaan Indeks Massa Tubuh yang signifikan pada kedua kelompok tersebut. ${ }^{19}$

Tabel 5. Karakteristik Responden berdasarkan berdasarkan Forearm Girth $10 \mathrm{~cm}$

\begin{tabular}{cccc}
\hline Kelompok & Mean \pm SD & P value & Keterangan \\
\hline Hand gripper exercise & $21,45 \pm 2,11$ & \multirow{2}{*}{0,407} & Tidak \\
Isometric strengthening wrist & $22,15 \pm 1,52$ & & Berbeda \\
\hline
\end{tabular}

Tabel 5. menunjukkan bahwa dari 20 sampel yang diamati, dapat di informasikan bahwa rerata Forearm Girth, pada kelompok Hand Gripper Exercise 21,45 menurut Widardo dkk pada tahun 2017 yaitu termasuk dalam kategori normal untuk forearm girth $10 \mathrm{~cm}$ sedangkan pada kelompok Isometric Strengthening Wrist memiliki mean sebesar 22,15 juga termasuk dalam kategori normal. Setelah dilakukan pengujian pada usia kedua kelompok diketahui nilai $p$ sebesar 0,407 yang dapat diartikan bahwa tidak ada perbedaan forearm girth $10 \mathrm{~cm}$ yang signifikan pada kedua kelompok tersebut. ${ }^{20}$

Tabel 6. Karakteristik Responden berdasarkan berdasarkan Forearm Girth $20 \mathrm{~cm}$

\begin{tabular}{cccc}
\hline Kelompok & Mean \pm SD & P value & Keterangan \\
\hline Hand gripper exercise & $18,40 \pm 1,63$ & \multirow{2}{*}{0,936} & Tidak \\
Isometric strengthening wrist & $18,45 \pm 1,04$ & & Berbeda
\end{tabular}

Tabel 6. menunjukkan bahwa dari 20 sampel yang diamati, dapat di informasikan bahwa rerata Forearm Girth $20 \mathrm{~cm}$, pada kelompok Hand Gripper Exercise 18,40 menurut Widardo dkk pada tahun 2017 yaitu termasuk dalam kategori normal untuk forearm girth $20 \mathrm{~cm}$ sedangkan pada kelompok Isometric Strengthening Wrist memiliki mean sebesar 18,45 juga termasuk dalam kategori normal. Setelah dilakukan pengujian pada forearm girth $20 \mathrm{~cm}$ kedua kelompok diketahui nilai p sebesar 0,936 yang dapat diartikan bahwa tidak ada perbedaan forearm girth $20 \mathrm{~cm}$ yang signifikan pada kedua kelompok tersebut. ${ }^{20}$

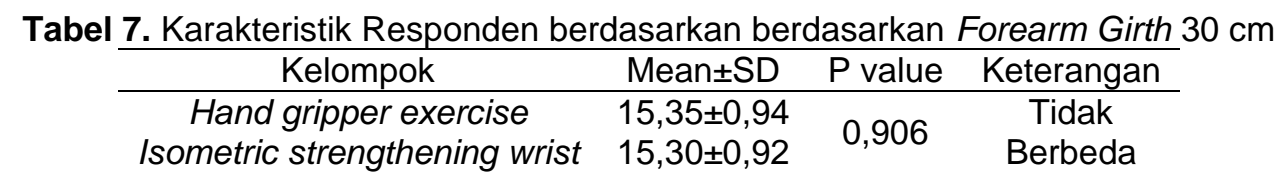

Tabel 7. menunjukkan bahwa dari 20 sampel yang diamati, dapat di informasikan bahwa rerata Forearm Girth $30 \mathrm{~cm}$, pada kelompok Hand Gripper Exercise 15,35 menurut Widardo dkk pada tahun 2017 yaitu termasuk dalam kategori yang normal untuk forearm girth $30 \mathrm{~cm}$ sedangkan pada kelompok Isometric Strengthening Wrist memiliki rerata sebesar 15,30 juga termasuk dalam kategori normal. Setelah dilakukan pengujian pada forearm girth $30 \mathrm{~cm}$ kedua kelompok diketahui nilai $p$ sebesar 0,906 yang dapat diartikan bahwa tidak ada perbedaan forearm girth $30 \mathrm{~cm}$ yang signifikan pada kedua kelompok tersebut. ${ }^{20}$ 
Tabel 8. Hasil Uji Normalitas

\begin{tabular}{ccccccc}
\hline & \multicolumn{3}{c}{ Kolmogrov-Smirnov } & \multicolumn{3}{c}{ Shapiro-Wilk } \\
\cline { 2 - 7 } & Statistic & Df & Sig. & Statistic & df & Sig. \\
\hline Pre-Handgripper & 0,296 & 10 & 0,134 & 0,785 & 10 & 0,109 \\
\hline Post-Handgripper & 0,320 & 10 & 0,104 & 0,760 & 10 & 0,105 \\
\hline Pre-Isometric Strengthening Wrist & 0,214 & 10 & 0,200 & 0,884 & 10 & 0,145 \\
\hline Post-Isometric Strengthening Wrist & 0,140 & 10 & $0,200^{*}$ & 0,928 & 10 & 0,428 \\
\hline
\end{tabular}

Berdasarkan Tabel 8. hasil pengujian uji normalitas data dapat disimpulkan bahwa pasangan kelompok berdistribusi normal, sehingga untuk pengujian bivariate dilakukan menggunakan uji parametrik.

Tabel 9. Uji Homogenitas

\begin{tabular}{cccc}
\hline Levene Statistik & df1 & df2 & Sig \\
\hline 2,911 & 1 & 18 & 0,105 \\
\hline
\end{tabular}

Data hasil penelitian yang sudah dilakukan, kemudian di uji homogenitas dengan menggunakan uji Levene's test. Berdasarkan hasil pengujian homogenitas menunjukkan nilai sig 0,105 $>0,05$ sehingga pada uji homogenitas data bersifat homogen.

Tabel 10. Karakteristik Responden berdasarkan Kekuatan Otot Genggam Sebelum dan Sesudah Melakukan Latihan

\begin{tabular}{cccc}
\hline Kelompok & Mean \pm SD & $\mathrm{P}$ value & Keterangan \\
\hline Hand gripper exercise & $16,75 \pm 7,34$ & 0,171 & $\begin{array}{c}\text { Tidak } \\
\text { Berbeda }\end{array}$ \\
Isometric strengthening wrist & $12,54 \pm 5,80$ & & d \\
\hline
\end{tabular}

Berdasarkan Tabel 10. menunjukkan bahwa nilai $p$ sebesar 0,171 yang dapat diartikan bahwa tidak ada perbedaan kekuatan otot genggam sebelum dilakukannya latihan.

Tabel 11. Hasil Uji Beda Nilai Kemampuan Aktivitas Fungsional Lansia

Sebelum dan Sesudah Intervensi pada Masing-Masing Kelompok

\begin{tabular}{cccc}
\hline Kelompok & Pre & Post & p value \\
\hline Hand Gripper Exercise & $16,7 \pm 7,34$ & $20,9 \pm 5,75$ & 0,001 \\
\hline Isometric Strengthening Wrist & $12,5 \pm 5,80$ & $14,6 \pm 5,55$ & 0,000 \\
\hline
\end{tabular}

Setelah dilakukan uji homogenitas, dari data hasil penelitian yang telah didapat kemudian dilanjutkan dengan uji Perbedaan Berpasangan untuk mengetahui perbedaan kemampuan aktivitas fungsional pada lansia. Berdasarkan hasil pada Tabel 11. terdapat perbedaan kemampuan aktivitas fungsional sebelum dan sesudah perlakuan pada kelompok pemberian dengan Hand Gripper Exercise. Menurut hasil analisis di atas dapat diketahui bahwa lansia yang diberikan perlakuan Hand Gripper Exercise pada awalnya 16,7 $\pm 7,34$ setelah diberikan perlakuan, kekuatan genggam otot meningkat menjadi 20,9 $\pm 5,75$. Hasil pengujian menggunakan uji Paired $T$ - test didapat $p$ value $=0,001(\alpha=0,05)$ yang artinya $p$ value $<0,05$, sehingga dapat dinyatakan bahwa terdapat perbedaan kekuatan otot genggam pada lansia sebelum dan sesudah perlakuan.

Berdasarkan hasil pada Tabel 11. dapat diketahui perbedaan kemampuan aktivitas fungsional sebelum dan sesudah perlakuan dengan Isometric Strengthening Wrist. Menurut hasil analisis diatas dapat diketahui bahwa lansia yang diberikan perlakuan Isometric Strengthening Wrist yang awalnya 12,5 $\pm 5,80$ setelah diberikan perlakuan, kekuatan otot genggam meningkat menjadi 14,6 $\pm 5,55$. Hasil pengujian menggunakan uji Paired $T$ - test didapat $p$ value $=0,000$ $(\alpha=0,05)$ yang artinya bahwa $p$ value $<0,05$, sehingga dapat dinyatakan bahwa terdapat perbedaan kekuatan otot genggam pada lansia sebelum dan sesudah perlakuan. Berdasarkan hasil analisis diatas dapat dikatakan bahwa Isometric Strengthening Wrist ( $\mathrm{p}$ value $=0,000)$ lebih signifikan dibandingkan Hand Gripper Exercise $(\mathrm{p}$ value $=0,001)$.

Tabel 12. Hasil Uji Nilai Selisih Kemampuan Aktivitas Fungsional Lansia pada Kelompok Hand Gripper Exercise dan Isometric Strengthening Wrist

\begin{tabular}{crr}
\hline Kelompok & Mean \pm SD & p value \\
\hline Hand Gripper Exercise & $4,21 \pm 2,29$ & \\
\hline Isometric Strengthening Wrist & $2,14 \pm 1,34$ & 0,023
\end{tabular}

Setelah dilakukan uji Perbedaan Berpasangan, selanjutnya untuk menganalisa perbedaan efek yang ditimbulkan oleh kedua kelompok yaitu Hand Gripper Exercise dengan Isometric Strengthening Wrist dilakukan dengan uji T-Independent. Berdasarkan tabel 12 diketahui nilai $p$ value $=0,023$ yang artinya pada taraf signifikansi $5 \%$ nilai $p$ $<0,05$, sehingga hipotesa dalam penelitian ini diterima dimana secara statistik dapat diartikan bahwa terdapat perbedaan yang signifikan efektifitas kekuatan otot genggam menggunakan latihan Hand Gripper Exercise dengan latihan Isometric Strengthening Wrist dalam meningkatkan kemampuan aktivitas fungsional pada lansia di Banjar Sanglah Utara Denpasar. Berdasarkan hasil tersebut juga didapatkan prosentase perubahan IADL Isometric Strengthening Wrist sebesar 90,64\%, sedangkan pada kelompok Hand Gripper Exercise terjadi perubahan IADL sebesar $89,26 \%$. 


\section{DISKUSI}

\section{Karakteristik Responden}

Total dari lansia yang terdapat di Banjar Sanglah Utara Denpasar adalah 57 orang terdiri dari 34 orang berjenis kelamin perempuan dan 23 orang berjenis kelamin pria. Rentang usia lansia di Banjar Sanglah Utara Denpasar adalah 60-80 tahun, sehingga pesebaran umur yang telah didapatkan pada penelitian ini adalah rentang usia 60-78 tahun didapat melalui anamnesis. Tabel 1 menunjukkan karakteristik responden berdasarkan usia pada kelompok Hand Gripper Exercise 69,1 dengan simpang baku \pm 6,31 sedangkan pada kelompok Isometric Strengthening Wrist sebesar 69,9 dengan simpang baku $\pm 5,25$. Hal tersebut juga serupa dengan penelitian Wikananda pada tahun 2015 yang menyatakan bahwa lansia memiliki usia 60-80 tahun dengan rerata 67,2 dan simpang baku $\pm 5,77$. Responden yang menjadi sampel telah dipilih berdasarkan kriteria inklusi dan eksklusi dengan menggunakan metode purposive sampling. Sesuai dengan rumus yang digunakan maka jumlah sampel dalam penelitian ini adalah 20 orang yang terdiri dari dua kelompok yaitu kelompok dengan latihan kekuatan otot genggam menggunakan Hand Gripper Exercise dan kelompok latihan kekuatan otot genggam dengan Isometric Strengthening Wrist masing-masing sebanyak 10 orang.

Kekuatan otot genggam menjadi faktor utama dalam menunjang aktivitas sehari-hari. Kekuatan otot genggam memiliki hubungan dengan pemeriksaan kekuatan otot lainnya. ${ }^{10}$ Oleh karena itu, kekuatan otot genggam dapat dikatakan mampu mewakili seluruh kekuatan otot dalam tubuh. Kekuatan otot genggam juga menjadi faktor yang penting dalam meningkatkan aktivitas fungsional lansia. Tabel 2 menyatakan bahwa rerata kekuatan otot genggam sebelum diberikannya latihan, pada kelompok Hand Gripper Exercise 16,75 dengan simpang baku \pm 7,34 sedangkan pada kelompok Isometric Strengthening Wrist sebesar 12,54 dengan simpang baku $\pm 5,80$. Pernyataan tentang rerata dan simpang baku pada kelompok Hand Gripper Exercise serupa dengan penelitian Dhote dkk pada tahun 2017 (ratarata sebesar 17,4 dengan simpang baku $\pm 5,8$ ) dan Putri tahun 2017 (rata-rata sebesar 16,8 dengan simpang baku \pm 5,0).2,10 Menurut American Medical Association dalam Lenardt 2015, memperkirakan bahwa $10-25 \%$ orang di atas 65 tahun memiliki kekuatan otot yang lemah dan prevalensi ini meningkat secara proposional dengan bertambahnya usia. ${ }^{6}$ Selain itu, pada penelitian Ong dkk pada tahun 2017 mengatakan bahwa tidak terdapat perbedaan yang signifikan antara jenis kelamin (laki-laki maupun perempuan), ras, dan etnis. Hasil dari penelitian ini menyatakan bahwa pemberian latihan kekuatan otot genggam lansia dapat meningkatkan aktivitas fungsional lansia. ${ }^{11}$

\section{Perbedaan Sebelum dan Sesudah Melakukan Latihan Kekuatan Otot Genggam Hand Gripper Exercise}

Berdasarkan hasil pengujian data dengan Paired $T$ - Test pada jumlah data penelitian sebanyak 20 responden, didapatkan nilai $p$ sebesar 0,001 . Hasil analisis perbedaan kemampuan aktivitas fungsional pada lansia menggunakan Hand Gripper Exercise didapatkan nilai $\mathrm{p}<0,05$. Sebagaimana hasil penelitian diatas menyatakan bahwa hipotesis peneliti dapat diterima. Maka dapat disimpulkan bahwa terdapat perbedaan hasil sebelum dan sesudah melakukan latihan kekuatan otot genggam menggunakan Hand Gripper pada lansia di Banjar Sanglah Utara.

Faktor-faktor yang dapat mempengaruhi kekuatan otot genggam adalah cenderung kuat pada tangan yang dominan, status gizi, usia, dan forearm girth. ${ }^{12}$ Kekuatan otot genggam erat memiliki hubungan dengan fungsi otot lainnya yang dapat menjadi salah satu prediktor dalam menilai gangguan mobilitas lansia. Lansia yang memiliki kekuatan otot genggam yang lemah akan mempengaruhi aktivitas fungsional atau aktivitas sehari-harinya. Menurut penelitian lain yaitu Vasconcelos dkk tahun 2016 juga mengatakan bahwa kekuatan otot genggam merupakan salah satu ukuran untuk mengidentifikasi adanya kelemahan otot dan keterbatasan mobilitas yang dapat berpengaruh terhadap kemampuan aktivitas fungsional pada lansia. Hal ini telah terbukti signifikan didalam penelitian yang telah dilakukan. ${ }^{13}$

Kemampuan aktivitas fungsional adalah kemampuan individu dalam menggunakan kapasitas fisik yang digunakan untuk menjalankan aktivitas sehari-hari seperti berintegrasi dan berinteraksi dengan lingkungannya. ${ }^{14}$ Kemampuan aktivitas fungsional dikatakan mandiri apabila seseorang mampu melaksanakan aktivitas sehari-harinya. ${ }^{10}$ Dalam penelitian ini aktivitas sehari-hari (Activity Daily Living) dapat diukur dengan menggunakan kuisioner IADL yang dimana dilakukan sebelum dan sesudah diberikannya latihan. Contoh dari aktivitas sehari-hari yang terdapat pada kuisioner IADL yaitu mencuci pakaian, mengoperasikan telepon genggam, menyiapkan obat hingga menggunakan transportasi, sehingga dapat diketahui dari hasil penelitian pada tabel 11 terdapat peningkatan aktivitas fungsional setelah diberikannya perlakuan berupa latihan kekuatan otot genggam menggunakan Hand Gripper $(20,9 \pm 5,75)$, yang sebelum diberikannya perlakuan $(16,7 \pm 7,34)$. Hasil ini serupa dengan penelitian Dhote dkk pada tahun 2017 bahwa setelah dilakukannya latihan kekuatan otot genggam menggunakan Hand Gripper dapat meningkatkan aktivitas fungsional pada lansia. ${ }^{10}$

\section{Perbedaan Sebelum dan Sesudah Melakukan Latihan Kekuatan Otot Genggam Isometric Strengthening Wrist}

Berdasarkan hasil pengujian data dengan Paired T-Test pada jumlah data penelitian sebanyak 20 responden, didapatkan nilai $p$ sebesar 0,000 . Hasil analisis perbedaan kemampuan aktivitas fungsional pada lansia menggunakan Isometric Strengthening Wrist didapatkan nilai $p<0,05$. Sebagaimana hasil penelitian diatas menyatakan bahwa hipotesis peneliti dapat diterima. Maka dapat disimpulkan bahwa terdapat perbedaan hasil sebelum dan sesudah melakukan latihan kekuatan otot genggam Isometric Strenthening Exercise pada lansia di Banjar Sanglah Utara.

Menurut penelitian Souza dkk tahun 2017 latihan isometric strengthening wrist berguna untuk mengaktifkan latihan gerakan seperti pinch grip lateral dan sebagai aktivator otot ekstensor pergelangan tangan pada jari-jari lansia. ${ }^{15}$ Menurut penelitian Holmes dkk tahun 2017 bahwa latihan isometric strengthening wrist dilakukan selama 5 minggu dengan frekuensi 3 kali dalam satu minggu dan menurut Bhardwaj dkk tahun 2011 dilakukan selama 5 detik dengan jeda waktu istirahat 10 detik telah terbukti signifikan dalam penelitian ini. ${ }^{9,16}$ Meningkatkan kekuatan otot genggam adalah salah satu program pemeliharan kesehatan, maka dari itu perlu dilakukan untuk membantu meningkatkan aktivitas fungsional pada lansia. Dalam penelitian ini aktivitas sehari-hari atau aktivitas fungsional (Activity Daily Living) 
dapat diukur dengan menggunakan kuisioner IADL yang dimana dilakukan sebelum dan sesudah diberikannya latihan. Dapat diketahui dari hasil penelitian pada tabel 11 terdapat peningkatan kemampuan aktivitas fungsional setelah diberikannya perlakuan berupa latihan kekuatan otot genggam Isometric Strengthening Wrist $(14,6 \pm 5,55)$, yang sebelum diberikannya perlakuan $(12,5 \pm 5,80)$. Hasil ini serupa dengan penelitian Souza dkk pada tahun 2017 bahwa setelah dilakukannya latihan kekuatan otot genggam Isometric Strengthening Wrist dapat meningkatkan aktivitas fungsional pada lansia. ${ }^{15}$

\section{Perbedaan Nilai Selisih Kemampuan Aktivitas Fungsional Lansia pada Kelompok Hand Gripper Exercise dan Isometric Strengthening Wrist}

Latihan Hand Gripper Exercise adalah salah satu latihan untuk meningkatkan kekuatan otot genggam menggunakan alat berupa hand gripper. Hasil pada peneltian ini serupa dengan penelitian yang dilakukan oleh Mathiowetz pada tahun 2008 bahwa latihan Hand Gripper Exercise dilakukan selama 5 minggu dengan frekuensi 3 kali dalam seminggu, serta 10 kali repitisi terbukti efektif. ${ }^{17}$ Selain itu hasil yang serupa dengan penelitian Dhote dkk pada tahun 2017 bahwa menggenggam hand gripper selama 5 detik dan diberikan jeda waktu 10 detik telah terbukti efektif mampu meningkatkan aktivitas fungsional pada lansia. ${ }^{10}$ Pada tabel 11 dikatakan terdapat peningkatan kekuatan otot genggam sebelum dan sesudah diberikannya latihan.

Selain latihan Hand Gripper Exercise pada penelitian ini juga terdapat latihan Isometric Strengthening Wrist yang diteliti. Latihan Isometric Strengthening Wrist adalah latihan kekuatan otot genggam menggunakan wrist and hand menggunakan latex flexiband ke arah medial. ${ }^{15}$ Latihan ini telah dilakukan kepada 10 responden yang telah dipilih secara acak menggunakan lotre sesuai kriteria eksklusi dan inklusi. Pada tabel 11 latihan kekuatan otot genggam Isometric Strengthening Exercise telah terbukti efektif dalam meningkatkan aktivitas fungsional pada lansia di Banjar Sanglah Utara Denpasar.

Hasil penelitian didapatkan melalui kuisioner IADL yang berguna untuk mengetahui tingkat kemampuan lansia dalam melakukan aktivitas sehari-harinya. Sebelum penelitian terdapat 16 orang yang termasuk dalam ketergantungan ringan dan 4 orang termasuk dalam ketergantungan sedang. Hasil setelah melakukan latihan kekuatan otot genggam berupa Hand Gripper Exercise dan Isometric Strengthening Wrist yang sebelumnya diperoleh hasil ketergantungan ringan adalah menjadi mandiri dan yang mendapatkan hasil ketergantungan sedang menjadi ketergantungan ringan. Hal ini serupa dengan penelitian milik Ryoto pada tahun 2012 yang menyatakan latihan kekuatan otot genggam dapat meningkatkan aktivitas fungsional pada lansia. ${ }^{18}$

Latihan kekuatan otot genggam Isometric Strengthening Wrist dan Hand Gripper Exercise memiliki perbedaan efektifitas yang signifikan. Pada tabel 12 perbedaan efektifitas antara kedua latihan memiliki taraf signifikansi $5 \%$. Selain itu telah didapat penilaian efektifitas antara latihan kekuatan otot genggam hand gripper exercise dan isometric strengthening wrist pada lansia di Banjar Sanglah Utara Denpasar mendapatkan nilai $p=0,023$ yang artinya hipotesa peneliti dapat diterima karena terdapat perbedaan yang signifikan antara latihan menggunakan Hand Gripper Exercise dengan latihan Isometric Strengthening Exercise dalam meningkatkan kemampuan aktivitas fungsional pada lansia.

\section{KESIMPULAN}

Berdasarkan hasil penelitian yang telah dilakukan dapat disimpulkan sebagai berikut :

1. Latihan kekuatan otot genggam hand gripper exercise dapat meningkatkan aktivitas fungsional pada lansia (nilai $\mathrm{p}=0,001)$.

2. Latihan kekuatan otot genggam isometric strengthening wrist dapat meningkatkan aktivitas fungsional pada lansia (nilai $p=0,000)$.

3. Terdapat perbedaan efektifitas (nilai $\mathrm{p}=0,023$ ) antara latihan kekuatan otot genggam hand gripper exercise dan isometric strengthening wrist dalam meningkatkan aktivitas fungsional pada lansia di Banjar Sanglah Utara Denpasar.

\section{REFERENSI}

1. Wikananda, G. Hubungan Kualitas Hidup dan Faktor Resiko pada Usia Lanjut di Wilayah Kerja Puskesmas Tampaksiring Kabupaten Gianyar Bali. 2015;7(1):1-12.

2. Putri, N, Purnawati, S. Hubungan Kekuatan Otot Genggam dan Kemampuan Fungsional pada Lansia Wanita di Posyandu Lansia Dauh Puri Kelod Denpasar Barat.E-Jurnal Medika. 2017;6(4):20-27

3. World Health Organization. Definition of Adult and Elders [Internet]. 2013 [cited 12 September 2019]. Available from: https://www.who.int/news-room/fact-sheets/detail/ageing-and-health

4. Kementrian Kesehatan RI. Situasi dan Analisis Lanjut Usia [Internet]. InfoDATIN. 2014 [cited 12 September 2019]. Available from: http://www.depkes.go.id/folder/view/01/structure-publikasi-data-pusat-data-dan-informasi.html

5. Badan Pusat Statistik Penduduk Lanjut Usia. Proyeksi, Analisis, dan Kumpulan Data Penduduk Lanjut Usia [Internet]. 2014 [cited 12 September 2019]. Available from: https://denpasarkota.bps.go.id/

6. Lenardt, M, Binotto, M, Carneiro, NHK, Cechinel, C, Betiolli, SE, Lourenco, TM. Handgrip Strength and Physical Activity in Frail Elderly. Journal of School of Nursing. 2015;50(1):86-92. http://dx.doi.org/10.1590/S0080623420160000100012

7. El Sais, W, Mohammad, W. Influence of Different Testing Postures on Hand Grip Strength. European Scientific Journal. 2014;10(36): 290-301

8. Wagner, P.R, Ascenco, S, Wibelinger, L.M. Hand Grip Strength in the Elderly with Upper Limbs Pain. Journal of Physiotherapy. 2011;15(3):182-185 
9. Holmes, M, Taylor, S, Miller, C \& Brewster, M.B.S 2017. Early Outcomes of The Birmingham Wrist Instability Programme'. Journal of Hand Therapy. 2017;22(3):90-100. sagepub.co.uk/journalsPermissions.nav doi: $10.1177 / 1758998316685469$ journals.sagepub.com/home/hth

10. Dhote, $P$, Deshpande, M \& Mendhe, K. Effect of Hand Grip Exercise on Finger Dexterxity in Geriatric Population Using Nine-Hole Peg Board Test: A Pilot Study. International Journal of Pharma and Bio Sciences. 2017;8(4):484488. http://dx.doi.org/10.22376/ijpbs.2017.8.4.b484-488

11. Ong, H, Abdin, E,Chua, B, Seow, E, Vainangkar, J, Chong, S \& Subramaniam, M. Hand Grip Strength Among Older Adults in Singapore: A Comparison with International Norms and Associative Factors. Journal BMC Geriatrics. 2017;17(176):1-12. DOI 10.1186/s12877-017-0565-6

12. Manoharan, V.S, Sundaram, S.G \& Jason, J.I. Factors Affecting Hand Grip Strength and Its Evaluation: A Systematic Review. International Journal Physiotherapy and Research. 2015;3(6):1288-1293

13. Vasconcelos, K.S, Dias, D, Baston, A.D.C, Vieira, R.A, Andrade, A.C.D, Parracini, M.R \& Dias, C.R. Handrgrip Strength Cuttoff Points to Identify Mobility Limitation in Community-Dwelling Older People and Associated Factors. Journal Nutriton Health Aging. 2016;20(3)

14. Semariasih, N.K.D. Hubungan Kekuatan Otot Genggam dengan Tingkat Kemandirian Kemampuan Fungsional pada Lansia Wanita di Desa Tista Kecamatan Kerambitan Tabanan [skripsi]. Denpasar: Fakutas Kedokteran Universitas Udayana Program Studi Fisioterapi; 2018.

15. Souza, V, Claudino, F, Kuriki, H.U, Marcolino, A.M, Fonseca, M, \& Barbosa I.R. Fatigue of The Wrist Extensor Muscles Decreases Palmar Grip Strength. 2017:100-107. http:// dx.doi.org: 10.1590/1809-2950/17328524012017

16. Bhardwaj, P, Nayak S.S, Kiswar, A.M, Sabapathy, R.S. Effect of Isometric Strengthening Wrist Posisition on Grip Strength. Indian Journal of Plastic Surgery. 2011;44(1);55-58. http://dx.doi.org/www.ijps.org/doi 10.4103/09700358.81440

17. Mathiowetz, V, Kashman, N, Volland, G, Weber, K, Dowe, M \& Roger, S. Grip and Pinch Grip Strength: Normative Data for Adults. Arch Phys Med Rehabil. 2018;(66):69-72

18. Ryoto, V. Hubungan antara Kekuatan Otot Genggam dengan Umur, Tingkat Kemandirian, dan Aktivitas Fisik pada Lansia Klub Geriatri Terpilih Jakarta Utara Tahun [skripsi]. Depok: Universitas Indonesia; 2012.

19. Kementrian Kesehatan RI. Analisis Lanjut Usia Data Tahun 2016 [Internet]. InfoDATIN. 2016 [cited 12 September 2019]. Available from: https://www.kemkes.go.id/folder/view/01/structure-publikasi-pusdatin-info-datin.html

20. Widardo, Wiboworini, B, Wiyono, N, Damayanti, E.K, Wulandari, S \& Hastuti, H. Buku Manual Ketrampilan Klinik Topik Antropometri dan Penilaian Status Gizi. Solo. Kementrian Riset, Teknologi, dan Pendidikan Tinggi Universitas Sebelas Maret; 2017. 